\title{
The Effect of a Sugar-Containing Preservative on Senescence-Related Processes in Cut Clematis Flowers
}

\author{
Julita RABIZA-ŚWIDER*, Ewa SKUTNIK, Agata JĘDRZEJUK \\ Warsaw University of Life Sciences, Faculty of Horticulture, Biotechnology and Landscape Architecture, Department of Ornamental Plants, \\ Nowoursynowska 166,02-787Warsaw, Poland; julita_rabiza_swider@sggw.pl ( ${ }^{*}$ corresponding author); \\ ewa_skutnik@sggw.pl;agata_jedrzejuk@sggw.pl
}

\begin{abstract}
Clematis is a new species grown as cut flower, whose vase life is variable and cultivar-depended. Little is known about senescence of its cut flowers and their response to flower preservatives. The aim of the study was to evaluate the effect of a preservative (standard preservative SP, 8-hydroxyquinoline citrate plus sucrose) or a biocide solution (8-HQC) on certain senescence-related processes in cut clematis flowers. Analyses were done immediately after harvest and at the end of the vase life when control flowers held in water were wilting. A possible relationship between senescence parameters and the vase life of clematis taxa was also sought. As in most cut flowers, the contents of reducing sugars and soluble proteins in clematis petals decreased during the vase life while the proteolytic activity, including that of the cysteine protease, increased and was accompanied by accumulation of free proline and ammonium. Cut flower longevity in cultivars under study was not associated with the initial levels of reducing sugars, soluble proteins or free proline. Neither was the initial proteolytic activity or its increase during vase life related to the vase life itself: cultivars having comparable life spans differed dramatically in the initial and final proteolytic activities. Both solutions containing 8-HQC significantly affected the senescence-related processes and flowers held in them had more soluble proteins and lower proteolytic activity (total, and that of the cysteine protease) than control flowers held in water. Approximately a twofold increase in reducing sugars was observed in flowers held in SP relative to those held in water or in 8-HQC while the accumulation of free proline and ammonium was limited in their petals. This suggests a regulating action of exogenous sugar in senescence of clematis flowers. However, the delay of senescence produced by the preservative was not always associated with a longer vase life in any given cultivar. Further studies are needed to elucidate the role of sugar in clematis flower senescence.
\end{abstract}

Keywords: ammonium; cysteine protease; free proline; proteolysis

Abbreviations: 8-HQC: 8-hydroxyquinoline citrate; DTT: dithiothreitol; EDTA: ethylenediaminetetraacetic acid; GS: glutamine synthetase; HEPES: N[2-hydroxyethyl]piperazine-N'-[4-butanesulfonic acid]; PCD: programmed cell death; S: sucrose; SP: standard preservative; TCA: trichloroacetic acid; U: unit

\section{Introduction}

Clematis is a popular vine with showy flowers. There is an increasing interest in growing it for cut flowers. Our previous studies have shown that clematis vase life depends on a cultivar, the harvest phase and postharvest treatments (Rabiza-Świder $e t$ al., 2017b). The vase lives of 17 cultivars tested so far ranged from 3 to 11 days, with 6-8 days being the most common. Such a relatively short vase life may be due to the fact that clematis flowers are harvested when fully open (Rabiza-Świder et al., 2017b). In such flowers, the process of senescence is already underway.
Some clematis cultivars respond positively to a preservative while in others, holding solutions have no effect on the vase life (Rabiza-Świder et al., 2017b). Preservatives delay a reduction of fresh weight and enhance water uptake but their effects on the postharvest longevity are not directly related to the water balance in cut clematis shoots (RabizaŚwider et al., 2017a). This raises the question as to what factors determine the effectiveness of postharvest treatments in clematis and how do they affect the course of senescence and the vase life in different clematis cultivars. What is the role of exogenous sugar, if any, in clematis petal senescence?

The beneficial effect of sugars on cut flower longevity is well known (Halevy and Mayak, 1979), although the mechanism of action of sucrose in delaying senescence is 
little understood (Eason et al., 1997). Sugars supplied to cut flowers are used as substrates for respiration, thereby preventing their rapid exhaustion, and thus delaying senescence (Courts et al., 1965). They maintain mitochondrial structure and function (Kaltaler and Steponkus, 1976), affect water status and maintain membrane function and protein synthesis (Halevy and Mayak, 1979), they regulate gene expression (Eason et al., 1997) and inhibit ethylene production (Pun and Ichimura, 2003). Clematis flowers do not produce ethylene in detectable amounts but are sensitive to exogenous ethylene (Rabiza-Świder et al., 2017b). Ichimura et al. (2000) suggest that ethylene production, or sensitivity to ethylene, may be related to internal carbohydrate levels. Sugars with biocides have become an important preservative for a range of cut flowers (Pun and Ichimura, 2003). The most frequently used - because of its simplicity and efficiency - is a solution of 8-hydroxyquinoline citrate (8-HQC) or 8hydroxyquinoline sulphate (8-HQS) with sucrose. These are called "the standard preservative".

The essential process in flower senescence is protein degradation (Vierstra, 1996) as a consequence of enzymatic proteolysis (Brzin and Kidrić, 1996; Vierstra, 1996; Azeez et al., 2007). Protein degradation during petal senescence has been characterized in several plants, including daylily (Stephenson and Rubinstein, 1998), alstroemeria (Wagstaff et al., 2002), carnation (Sugawara et al., 2002), iris (Pak and van Doorn, 2005), petunia (Jones et al., 2005) and sword lily (Azeez et al., 2007). The key group of proteases associated with senescence and programmed cell death (PCD) of plants are cysteine proteases (Valpuesta et al., 1995; Granell et al., 1998; Wagstaff et al., 2002; Jones et al., 2005).

Water stress has been shown to enhance clematis senescence (Jędrzejuk et al., 2012; Rabiza-Świder et al., 2017a), affecting - among others - nitrogen metabolism. In plants, water stress is correlated with a decline in the activity of glutamine synthetase (GS) (Feller and Fischer, 1994; Yang and Kao, 2000; Lin et al., 2002), the key enzyme in ammonium assimilation (Britto and Kronzucker, 2002). An increase in the proteolytic activity at the later stages of flower senescence can be an alternative metabolic pathway initiated to avoid ammonium ion accumulation, when the GS activity becomes limiting (Kumar et al., 2009 after Weinstein, 1957). In fact, various studies have shown accumulation of ammonium in the leaves during senescence (Chen et al., 1997; Lin et al., 2002) but there is little information on changes in the ammonium content in senescing flowers (Paulin, 1971) although ammonium is considered to be toxic to plant cells (Britto and Kronzucker, 2002). Ammonium ions are used in the GS pathway (Britto and Kronzucker, 2002) which leads to proline synthesis (Yang and Kao, 2000). Proline synthesis from glutamate is suggested to be the main mechanism of proline increase in plants under water stress (Fichman et al., 2015; Zhang and Becker, 2015). Proline accumulation might also be due to its reduced oxidation, reduced incorporation into proteins, and proteolysis (Karolewski, 1996). Studies of flowers have revealed that proline metabolism may have several impacts on petal senescence (Zhang and Becker, 2015). Proline is considered to be an important compatible solute that acts as a molecular chaperone stabilizing the structure of proteins, as well as a regulator of cellular redox potential and an antioxidant, controlling free radicals (Hong et al., 2000).

Flower senescence is a highly organized process comprising structural, biochemical and molecular changes leading to the disorganization, gradual cell degradation and finally to death of an organ or an organism (Rubinstein, 2000). Because clematis is a new species for floriculture, studies on senescence of its cut flowers are needed. This study was undertaken to analyze certain senescence-related processes in cut clematis flowers and to seek possible relationships between any of these parameters and the vase life. We describe several biochemical changes accompanying senescence in clematis, contrasting these occurring in flowers held in water with these in flowers supplemented with sucrose in hope to elucidate a role of exogenous sugar in clematis senescence.

\section{Materials and Methods}

\section{Experimental design}

Seventeen clematis (Clematis L.) cultivars were used as the experimental material (Table 1). Plants were kindly provided by the Clematis Sz. Marczyński and W. Piotrowski Nursery in Duchnice near Warsaw, Poland. The choice of these cultivars was based earlier observations of their vase lives (Rabiza-Świder $e t$ al., 2017b) and represent cut flowers with different, genetically based longevity (Table 1). Flowers were harvested at the same stage of development, in other words mature, open flowers with no visible symptoms of disease, pests or mechanical defects. Shoots were trimmed to $20 \mathrm{~cm}$ with one pair of leaves left and placed into vases. The treatments were: distilled water (control), 8-hydroxyquinoline citrate (8-HQC) in concentration $200 \mathrm{mg} \mathrm{L}^{-1}$ and the standard preservative (SP) containing $200 \mathrm{mg} \mathrm{L}^{-1} 8-\mathrm{HQC}$ and $20 \mathrm{~g} \mathrm{~L}^{-1}$ sucrose. The experiments were carried under controlled conditions: temperature $20{ }^{\circ} \mathrm{C}$, relative humidity $60 \%, 12 \mathrm{~h}$ photoperiod with light intensity of $35 \mu \mathrm{mol} \mathrm{m} \mathrm{m}^{-1} \mathrm{~s}^{-1}$ PAR. Usually two experiments were run in parallel and the flowers were treated similarly but separately. One experiment was on the flower vase life and its results have already been described (Rabiza-Świder $e t$ al., 2017b). The one presented here focuses on senescence.

\section{Experimental procedures}

Petals for analyses were collected at day 0 (immediately after harvest) and at the end of the vase life in control treatments (stems placed in water) of the respective taxa: 4 days after harvest for cultivars 'Doctor Ruppel' and 'Lech Wałęsa', 6 days after harvest for cultivars 'General Sikorski', 'Mazury', 'Multi Blue', 'Piilu', 'Rhapsody', 'Ville de Lyon', 'Warszawska Nike' and 'Westerplatte', 7 days after harvest for cultivars 'Kiri Te Kanawa' and 'Solidarność and 8 days after harvest for cultivars 'Arabella', 'Blue Light', 'Comtesse de Bouchand', 'Julka' and 'Maria Skłodowska-Curie' (Table 1). For each analysis 6 flowers were taken from each treatment. They were finely cut, evenly mixed and 3 samples of $0.5 \mathrm{~g}$ were taken for analyses. 
Table 1. The list of clematis cultivars used in the experiment

\begin{tabular}{|c|c|c|}
\hline Cultivar & Vase life in water (days) and response SP & No. of days till the 2 . analysis \\
\hline 'Arabella' & $11.0^{1} \downarrow$ & 8 \\
\hline 'Blue Light' & $11.0-$ & 8 \\
\hline 'Comtesse de Bouchand' & $9.8 \downarrow$ & 8 \\
\hline 'Doctor Ruppel' & $3.7 \downarrow$ & 4 \\
\hline 'General Sikorski' & $5.9 \uparrow$ & 6 \\
\hline 'Julka’ & $10.0-$ & 8 \\
\hline 'Kiri Te Kanawa' & $7.3 \uparrow$ & 7 \\
\hline 'Lech Wałęsa' & $4.3 \uparrow$ & 4 \\
\hline 'Maria Skłodowska-Curie' & $7.0 \uparrow$ & 8 \\
\hline 'Mazury' & $6.7 \uparrow$ & 6 \\
\hline 'Multi Blue' & $7.3 \downarrow$ & 6 \\
\hline 'Piilu' & $7.2-$ & 6 \\
\hline 'Rhapsody' & $5.5-$ & 6 \\
\hline 'Solidarność' & $8.9-$ & 7 \\
\hline 'Ville de Lyon' & $6.1 \uparrow$ & 6 \\
\hline 'Warszawska Nike' & $6.3-$ & 6 \\
\hline 'Westerplatte' & $7.3-$ & 6 \\
\hline
\end{tabular}

Three determinations were made for each sample, giving a total of 9 readings for each data point. Three samples were taken for dry weight. The material was dried at $105^{\circ} \mathrm{C}$ until constant weight. Results were calculated on the dry matter basis.

The reducing sugars content was measured by the Somogyi method modified by Nelson (1944), and expressed in $\mathrm{g} \mathrm{kg}^{-1}$ of dry weight. The material was homogenized in $80 \%$ ethanol. The extracts were incubated for 20 minutes in a boiling water bath with the copper reagent, the molybdenum arsenic reagent was added and the extinction was measured at $520 \mathrm{~nm}$. The amount of reducing sugar content was calculated from a previously plotted standard curve, prepared for glucose.

The total soluble protein content was determined by the Bradford's method (1976) and expressed in $\mathrm{g} \mathrm{kg}^{-1}$ of dry weight. Proteins were extracted in HEPES with $1 \mathrm{mmol} \mathrm{L}^{-1}$ DTT, 1 mmol L ${ }^{-1}$ EDTA, pH 7.5. The homogenate was centrifuged for 25 minutes at $6,573.84 \mathrm{~g}\left(4^{\circ} \mathrm{C}\right)$ and the Bradford's reagent (100 mg Camassie Blue in $50 \mathrm{ml} 95 \%$ ethanol, $100 \mathrm{ml} 85 \%$ orthophosphoric acid in $1,000 \mathrm{ml}$ distilled water) was added to the supernatant. The absorbance was read at $595 \mathrm{~nm}$. The amount of soluble protein was calculated from a previously plotted standard curve.

Total proteolysis and the activity of the cysteine protease were measured as described by Zagdańska and Wiśniewski (1996). Enzymes were extracted in HEPES with $1 \mathrm{mmol} \mathrm{L}^{-1}$ DTT and $1 \mathrm{mmol} \mathrm{L}^{-1}$ EDTA, pH 7.5. For proteolysis, the extract was incubated for $3 \mathrm{~h}$ at $37^{\circ} \mathrm{C}$ with the citricphosphate buffer $\mathrm{pH} 5.0$ and azocasein. For the cysteine protease activity, $10 \mathrm{mmol} \mathrm{L}^{-1}$ iod acetate was added to the extract-buffer mixture, with azocasein added after $1 \mathrm{~h}$ of incubation. The reaction was stopped by $24 \%$ TCA. Extinction was read against a blank at $340 \mathrm{~nm}$, and the protease activity was calculated as a difference in readings with and without the iod acetate. Results are given in arbitrary units (U) which correspond to changes in absorbance of 0.01 during $1 \mathrm{~h}$, calculated on mg of protein in the sample, as determined by the Bradford's method (1976).

The free proline content was tested according to Bates $e t$ al. (1973) by measuring the quantity of a colored reaction product of proline with ninhydric acid. The absorbance was read at $520 \mathrm{~nm}$. The amount of free proline was calculated from a previously plotted standard curve and expressed in mmol kg-1 of dry weight.

Ammonium was measured in the crude extract by the Berthelot reaction, modified according to Weatherburn (1967), described by Lin and Kao (1996). Samples were homogenized in $4 \mathrm{ml} 0.3 \mathrm{mmol} \mathrm{L}^{-1} \mathrm{H}_{2} \mathrm{SO}_{4}, \mathrm{pH} 3.5$, and the homogenate was centrifuged for 10 minutes at $6,573.84 \mathrm{~g}$ and the supernatant was used for determination of ammonium. Ammonium levels were expressed in mmol kg of dry weight.

\section{Statistical procedures}

Data were analyzed by the General Linear Model program of the IBM SPSS Statistics Data Editor (Softonic, Poland) and means were compared by the Duncan's test at the probability level $\mathrm{P}=95 \%$.

\section{Results}

\section{Reducing sugar content in cut clematisflowers}

The initial contents of reducing sugars in the phase of fully open flowers differed in different cultivars (Table 2). The lowest levels were recorded in cultivars 'Solidarność' and 'Lech Wałessa'; the highest in cv. 'Rhapsody', with an almost two-fold difference. In control flowers of most cultivars held in water the sugar levels dropped during vase life, 1.1 to 2.8 times relative to the initial levels. In cultivars 'Arabella', 'Multi Blue', 'Piilu', 'Rhapsody' and 'Warszawska Nike' no significant changes in the sugar content was observed during the vase life while in 'Doctor Ruppel' 
wilting petals contained $43 \%$ more sugars than at harvest. On the other hand, in flowers held in the preservative (SP) an accumulation of reducing sugars during vase life was observed, reaching levels approximately twice as high as in flowers held in water or in 8-HQC, and higher than in flowers at harvest (Table 2).

\section{Proteolysis in cut clematis flowers}

The levels of the initial soluble proteins were different in different cultivars tested (Table 3). The lowest levels were observed in the petals of cv. 'Lech Watesa' and the highest in cv. 'Blue Light'. Irrespective of the initial levels, the protein contents in flowers of all cultivars held in water drastically fell during vase life. A drop in the soluble protein contents was also observed in flowers of some cultivars held in both 8-HQC-containing solutions, but in most cases the protein contents in flowers held in 8-HQC or SP was higher than in respective controls (water).

The activity of proteolytic enzymes in freshly harvested flowers in different cultivars ranged widely (Table 4). A very low initial activity was observed in cultivars 'Arabella', Blue Light' and 'Rhapsody' while in cv. 'Lech Wałęsa' it was ca.
50 times higher. Regardless of the initial value, the activity increased during vase life in all flowers held in water. The highest - over 30-fold - increase was observed in cv. 'Blue Light'. This is the same cultivar where the proteolytic activity at harvest was the lowest. In wilting flowers of 10 out of 13 cultivars held in 8-HQC or SP, the activity of proteolytic enzymes was lower than in the respective controls.

The lowest activity of cysteine protease in freshly harvested flowers was observed in cultivars 'Arabella', 'Blue Light', 'Rhapsody' and 'Julka'; the highest was in cv. 'Lech Watęsa' (Table 5). The latter had the lowest initial content of soluble proteins (Table 3). The activity of cysteine protease increased during vase life, usually several times over the initial value. The most dramatic increase (34-fold) was in cv. 'Blue Light'. In flowers placed into biocide or the standard preservative this increase was limited and the activity of cysteine protease was lower than in flowers held in water. The exception was cv. 'Multi Blue' where the activity in flowers from all three treatments was similar to the initial level, and in cv. 'Rhapsody' where the activity was similar in three treatments.

Table 2. The effect of preservatives on contents of reducing sugars $\left(\mathrm{g} \mathrm{kg}^{-1}\right)$ in cut clematis flowers

\begin{tabular}{|c|c|c|c|c|}
\hline \multirow{2}{*}{ Cultivar } & \multirow{2}{*}{ After harvest ${ }^{1}$} & \multicolumn{3}{|c|}{ Postharvest treatment ${ }^{2}$} \\
\hline & & Water & 8-HQC & $8-\mathrm{HQC}+2 \% \mathrm{~S}$ \\
\hline 'Arabella' & CD $256.32 \mathrm{a}^{3}$ & $254.70 \mathrm{a}$ & $240.60 a$ & $374.04 b$ \\
\hline 'Blue Light' & D $278.22 \mathrm{c}$ & $98.94 \mathrm{a}$ & $92.22 \mathrm{a}$ & $218.52 \mathrm{~b}$ \\
\hline 'Doctor Ruppel' & CD $258.90 \mathrm{a}$ & $371.40 \mathrm{~b}$ & $270.54 \mathrm{a}$ & $471.60 \mathrm{c}$ \\
\hline 'General Sikorski' & D $278.76 b$ & $174.00 \mathrm{a}$ & $166.50 \mathrm{a}$ & $400.20 \mathrm{c}$ \\
\hline 'Julka' & BC $237.51 \mathrm{c}$ & $181.20 \mathrm{~b}$ & $160.32 \mathrm{a}$ & $330.25 \mathrm{~d}$ \\
\hline 'Lech Wałęsa' & $\mathrm{AB} 214.62 \mathrm{~b}$ & $183.76 \mathrm{a}$ & $170.51 \mathrm{a}$ & $381.42 \mathrm{c}$ \\
\hline 'Mazury' & E $331.20 \mathrm{~b}$ & $201.96 \mathrm{a}$ & $394.74 \mathrm{c}$ & $741.30 \mathrm{~d}$ \\
\hline 'Multi Blue' & E $325.20 \mathrm{a}$ & $343.80 \mathrm{a}$ & 309.18 a & $584.04 \mathrm{~b}$ \\
\hline 'Piilu' & B $218.46 \mathrm{ab}$ & $245.04 \mathrm{ab}$ & $201.72 \mathrm{a}$ & $657.90 \mathrm{c}$ \\
\hline 'Rhapsody' & F $363.72 \mathrm{a}$ & $376.32 \mathrm{a}$ & $501.90 \mathrm{~b}$ & $727.84 \mathrm{c}$ \\
\hline 'Solidarność' & A 183.96 b & $121.75 \mathrm{a}$ & $142.75 \mathrm{ab}$ & $363.31 \mathrm{c}$ \\
\hline 'Ville de Lyon' & EF $355.56 b$ & $311.40 \mathrm{a}$ & $461.76 \mathrm{c}$ & $493.02 \mathrm{~d}$ \\
\hline 'Warszawska Nike' & D $276.18 \mathrm{ab}$ & $303.72 \mathrm{~b}$ & $253.44 \mathrm{a}$ & $654.66 \mathrm{c}$ \\
\hline
\end{tabular}

${ }^{T}$ The reducing sugars content immediately after cutting flowers

${ }^{2}$ The reducing sugars content on a day when control flowers (of a given cultivar) kept in water lost their decorative value - see Material and Methods

${ }^{3}$ Means in the first column followed by the same capital letter do not differ significantly at probability level $\mathrm{P}=95 \%$. Means in each verse followed by the same small letter do not differ significantly at probability level $\mathrm{P}=95 \%$. Analyses were done separately for each cultivar.

Table 3. The effect of preservatives on contents of total soluble protein $\left(\mathrm{g} \mathrm{kg}^{-1}\right)$ in cut clematis flowers

\begin{tabular}{|c|c|c|c|c|}
\hline \multirow{2}{*}{ Cultivar } & \multirow{2}{*}{ After harvest $^{1}$} & \multicolumn{3}{|c|}{ Postharvest treatment $^{2}$} \\
\hline & & Water & 8-HQC & 8 -HQC $+2 \% \mathrm{~S}$ \\
\hline 'Arabella' & I $340.34 d^{3}$ & $50.44 \mathrm{a}$ & $112.92 \mathrm{c}$ & $77.78 \mathrm{~b}$ \\
\hline 'Blue Light' & K $756.96 \mathrm{~d}$ & $33.49 \mathrm{a}$ & $97.93 \mathrm{~b}$ & $89.09 \mathrm{~b}$ \\
\hline 'Doctor Ruppel' & DE 132.39 b & $40.20 \mathrm{a}$ & $37.44 \mathrm{a}$ & $40.64 \mathrm{a}$ \\
\hline 'General Sikorski' & $\mathrm{J} 705.02 \mathrm{~d}$ & $314.39 \mathrm{a}$ & $638.75 \mathrm{c}$ & $495.24 b$ \\
\hline 'Julka' & B 86.52 c & $22.85 \mathrm{a}$ & $26.03 \mathrm{~b}$ & $27.43 b$ \\
\hline 'Lech Wałęsa' & A $9.33 \mathrm{c}$ & $4.04 \mathrm{a}$ & $15.51 \mathrm{~d}$ & $5.88 \mathrm{~b}$ \\
\hline 'Mazury' & CD $115.89 c$ & $37.74 \mathrm{a}$ & $61.22 \mathrm{~b}$ & $55.34 \mathrm{~b}$ \\
\hline 'Multi Blue' & $\mathrm{H} 241.25 \mathrm{c}$ & $27.78 \mathrm{a}$ & $51.28 \mathrm{~b}$ & $39.37 \mathrm{ab}$ \\
\hline 'Piilu' & EF $145.43 b$ & $25.13 \mathrm{a}$ & $31.80 \mathrm{a}$ & $19.98 \mathrm{a}$ \\
\hline 'Rhapsody' & G 201.15 c & $57.37 \mathrm{a}$ & $64.79 \mathrm{a}$ & $115.96 \mathrm{~b}$ \\
\hline 'Solidarnośćc' & BC 105.22 c & $64.63 \mathrm{a}$ & $70.22 \mathrm{ab}$ & $83.40 \mathrm{~b}$ \\
\hline 'Ville de Lyon’ & BC $92.91 \mathrm{c}$ & $20.06 \mathrm{a}$ & $39.79 \mathrm{~b}$ & $31.43 \mathrm{ab}$ \\
\hline 'Warszawska Nike' & F 171.92 c & $49.60 \mathrm{a}$ & $62.49 \mathrm{ab}$ & $72.42 \mathrm{~b}$ \\
\hline
\end{tabular}

${ }^{\mathrm{T}}$ The total soluble protein content immediately after cutting flowers

${ }^{2}$ The total soluble protein content on a day when control flowers (of a given cultivar) kept in water lost their decorative value - see Material and Methods

${ }^{3}$ Means in the first column followed by the same capital letter do not differ significantly at probability level $\mathrm{P}=95 \%$. Means in each verse followed by the same small letter do not differ significantly at probability level $\mathrm{P}=95 \%$. Analyses were done separately for each cultivar. 
Table 4. The effect of preservatives on total proteolytic activity $\left(\mathrm{U} \mathrm{mg}^{-1}\right.$ protein $\left.\mathrm{h}^{-1}\right)$ in cut clematis flowers

\begin{tabular}{|c|c|c|c|c|}
\hline \multirow{2}{*}{ Cultivar } & \multirow{2}{*}{ After harvest ${ }^{1}$} & \multicolumn{3}{|c|}{ Postharvest treatment ${ }^{2}$} \\
\hline & & Water & 8-HQC & $8-\mathrm{HQC}+2 \% \mathrm{~S}$ \\
\hline 'Arabella' & A $0.70 a^{3}$ & $6.08 \mathrm{~b}$ & $6.04 b$ & $8.61 \mathrm{c}$ \\
\hline 'Blue Light' & A $1.05 \mathrm{a}$ & $32.87 \mathrm{c}$ & $8.54 b$ & $9.78 \mathrm{~b}$ \\
\hline 'Doctor Ruppel' & B 3.07 a & $16.01 \mathrm{~d}$ & $8.85 \mathrm{c}$ & $16.01 \mathrm{~d}$ \\
\hline 'Generał Sikorski’ & E $8.57 b$ & $11.28 \mathrm{~d}$ & $9.29 \mathrm{c}$ & $5.81 \mathrm{a}$ \\
\hline 'Julka' & $\mathrm{CD} 4.60 \mathrm{a}$ & $12.32 \mathrm{~b}$ & $3.50 \mathrm{a}$ & $16.59 \mathrm{c}$ \\
\hline 'Lech Walęsa' & F $42.57 \mathrm{c}$ & $68.78 \mathrm{~d}$ & $35.73 \mathrm{~b}$ & $14.80 \mathrm{a}$ \\
\hline 'Mazury' & BC $3.39 \mathrm{a}$ & $11.18 \mathrm{c}$ & $10.14 \mathrm{c}$ & $8.63 \mathrm{~b}$ \\
\hline 'Multi Blue' & CD $4.67 \mathrm{a}$ & $6.28 \mathrm{~b}$ & $4.49 \mathrm{a}$ & $5.19 \mathrm{ab}$ \\
\hline 'Piilu' & BCD $4.41 \mathrm{a}$ & $13.61 \mathrm{c}$ & $12.07 \mathrm{bc}$ & $11.42 \mathrm{~b}$ \\
\hline 'Rhapsody' & A $0.76 a$ & $6.28 \mathrm{~d}$ & $4.93 \mathrm{c}$ & $3.40 \mathrm{~b}$ \\
\hline 'Solidarność' & E $7.61 \mathrm{a}$ & $78.76 \mathrm{c}$ & $11.45 \mathrm{~b}$ & $8.49 \mathrm{~b}$ \\
\hline 'Ville de Lyon' & D $5.82 \mathrm{a}$ & $21.33 \mathrm{~d}$ & $11.55 \mathrm{~b}$ & $18.15 \mathrm{c}$ \\
\hline 'Warszawska Nike' & BC $3.57 \mathrm{a}$ & $11.89 \mathrm{c}$ & $9.97 \mathrm{~b}$ & $8.57 \mathrm{~b}$ \\
\hline
\end{tabular}

${ }^{2}$ The total proteolytic activity on a day when control flowers (of a given cultivar) kept in water lost their decorative value - see Material and Methods

${ }^{3}$ Means in the first column followed by the same capital letter do not differ significantly at probability level $\mathrm{P}=95 \%$. Means in each verse followed by the same small letter do not differ significantly at probability level $\mathrm{P}=95 \%$. Analyses were done separately for each cultivar.

Table 5. The effect of preservatives on activities of cysteine protease $\left(\mathrm{U} \mathrm{mg}^{-1}\right.$ protein $\left.\mathrm{h}^{-1}\right)$ in cut clematis flowers

\begin{tabular}{|c|c|c|c|c|}
\hline \multirow{2}{*}{ Cultivar } & \multirow{2}{*}{ After harvest ${ }^{1}$} & \multicolumn{3}{|c|}{ Postharvest treatment $^{2}$} \\
\hline & & Water & 8-HQC & $8-\mathrm{HQC}+2 \% \mathrm{~S}$ \\
\hline 'Arabella' & A $0.52 a^{3}$ & $4.65 c$ & $3.41 \mathrm{~b}$ & $3.70 \mathrm{~b}$ \\
\hline 'Blue Light' & A $0.73 \mathrm{a}$ & $25.32 \mathrm{~d}$ & $5.58 \mathrm{~b}$ & $7.98 \mathrm{c}$ \\
\hline 'Doctor Ruppel' & $\mathrm{BC} 2.91 \mathrm{a}$ & $11.97 \mathrm{~d}$ & $8.81 \mathrm{c}$ & $5.63 \mathrm{~b}$ \\
\hline 'Generał Sikorski’ & DE $4.35 \mathrm{c}$ & $5.38 \mathrm{~d}$ & $2.37 \mathrm{~b}$ & $0.88 \mathrm{a}$ \\
\hline 'Julka' & $\mathrm{AB} 1.71 \mathrm{a}$ & $7.22 \mathrm{~d}$ & $4.09 \mathrm{~b}$ & $5.76 \mathrm{c}$ \\
\hline 'Lech Wałęsa' & F9.53 a & $47.13 c$ & $23.48 \mathrm{~b}$ & $6.90 \mathrm{a}$ \\
\hline 'Mazury' & BC $2.74 b$ & $7.57 \mathrm{~d}$ & $4.26 c$ & $1.75 \mathrm{a}$ \\
\hline 'Multi Blue' & CD 3.59 a & $4.60 \mathrm{a}$ & $4.03 \mathrm{a}$ & $4.55 \mathrm{a}$ \\
\hline 'Piilu' & CD $3.64 \mathrm{a}$ & $11.19 \mathrm{c}$ & $6.81 \mathrm{~b}$ & $6.18 \mathrm{~b}$ \\
\hline 'Rhapsody' & A $0.58 \mathrm{a}$ & $4.30 \mathrm{c}$ & $2.97 \mathrm{c}$ & $4.03 \mathrm{c}$ \\
\hline 'Solidarność' & E $5.35 \mathrm{a}$ & $68.29 \mathrm{~b}$ & $5.00 \mathrm{a}$ & $3.56 \mathrm{a}$ \\
\hline 'Ville de Lyon' & DE $4.38 \mathrm{a}$ & $17.05 \mathrm{~d}$ & $10.51 \mathrm{~b}$ & $14.33 \mathrm{c}$ \\
\hline 'Warszawska Nike' & BC $2.56 \mathrm{a}$ & $8.36 \mathrm{~d}$ & $4.43 \mathrm{~b}$ & $5.84 \mathrm{c}$ \\
\hline
\end{tabular}

${ }^{\top}$ The cysteine protease activity immediately after cutting flowers

${ }^{2}$ The cysteine protease activity on a day when control flowers (of a given cultivar) kept in water lost their decorative value - see Material and Methods

${ }^{3}$ Means in the first column followed by the same capital letter do not differ significantly at probability level $\mathrm{P}=95 \%$. Means in each verse followed by the same small letter do not differ significantly at probability level $\mathrm{P}=95 \%$. Analyses were done separately for each cultivar.

\section{Free proline and ammonium in cut flowers}

Free proline levels were measured in six cultivars. The lowest levels in freshly harvested flowers were observed in cultivars 'Generał Sikorski' and 'Julka', while in cultivars 'Kiri Te Kanawa', 'Maria Skłodowska-Curie' and 'Westerplatte' these levels were almost twice as high (Table 6). In flowers of five out of six tested cultivars held in water the proline content increased during vase life, by the average of $36 \%$. The only exception was cv. 'Kiri Te Kanawa' where the free proline content in wilting control flowers was similar to the initial level.

Wilting petals of all cultivars held in SP had less free proline than those held in water (Table 6). Biocide solution produced variable responses: in three cultivars ('Comtesse de Bouchand', 'Generat Sikorski', 'Westerplatte') the proline level was lower than in respective controls, in two cultivars ('Kiri Te Kanawa', 'Maria Skłodowska-Curie') it was higher, while in cv. 'Julka' it was similar to the control.
The initial ammonium content in petals at harvest showed considerable variation among tested cultivars (Table 7). The lowest level was observed in cv. 'Maria Skłodowska-Curie'; the highest in cv. 'Julka', with a five-fold difference. The remaining four cultivars showed similar levels of ammonium. During the vase life of flowers held in water, the ammonium level dropped relative to the initial value by $23 \%$ and $9 \%$, respectively ('Julka', 'Kiri Te Kanawa'), while in four cultivars it increased: in 'Comtesse de Bouchand' by 28\%, in 'Generał Sikorski' and 'Maria Skłodowska-Curie' by $16 \%$, and in 'Westerplatte' by approximately $100 \%$. As compared to water controls, flowers of almost all cultivars held in the 8-HQC solution, and all cultivars held in the SP, had less ammonium. The lowest level was observed in 'Westerplatte' held in SP: it was 16.5 times lower than in control wilting flowers, and 8.4 times lower than the initial value at harvest. 
Table 6. The effect of preservatives on contents of free proline $\left(\mathrm{mmol} \mathrm{kg}^{-1}\right)$ in cut clematis flowers

\begin{tabular}{ccccc}
\hline \multirow{2}{*}{ Cultivar } & \multirow{2}{*}{ After harvest } & \multicolumn{3}{c}{ Postharvest treatment $^{2}$} \\
\cline { 3 - 5 } & & Water & 8 -HQC & 8 -HQC + 2\% S \\
\hline 'Comtesse de Bouchand' & B 11.50 b & $17.80 \mathrm{~d}$ & $15.70 \mathrm{c}$ & $6.20 \mathrm{a}$ \\
'Generał Sikorski' & $\mathrm{A} 9.35 \mathrm{~b}$ & $11.21 \mathrm{c}$ & $8.66 \mathrm{ab}$ & $7.61 \mathrm{a}$ \\
'Julka' & $\mathrm{A} 8.68 \mathrm{a}$ & $13.16 \mathrm{~b}$ & $13.37 \mathrm{~b}$ & $9.31 \mathrm{a}$ \\
'Kiri Te Kanawa' & $\mathrm{C} 16.26 \mathrm{~b}$ & $16.00 \mathrm{~b}$ & $20.64 \mathrm{c}$ & $8.96 \mathrm{a}$ \\
'Maria Skłodowska-Curie' & $\mathrm{C} 15.18 \mathrm{~b}$ & $20.48 \mathrm{c}$ & $22.01 \mathrm{~d}$ & $4.23 \mathrm{a}$ \\
'Westerplatte' & $\mathrm{C} 15.02 \mathrm{~b}$ & $17.67 \mathrm{c}$ & $15.08 \mathrm{~b}$ & $6.86 \mathrm{a}$ \\
\hline
\end{tabular}

The free proline content immediately after cutting flowers

${ }^{2}$ The free proline content on a day when control flowers (of a given cultivar) kept in water lost their decorative value - see Material and Methods

${ }^{3}$ Means in the first column followed by the same capital letter do not differ significantly at probability level $\mathrm{P}=95 \%$. Means in each verse followed by the same small letter do not differ significantly at probability level $\mathrm{P}=95 \%$. Analyses were done separately for each cultivar.

Table 7. The effect of preservatives on contents of ammonium $\left(\mathrm{mmol} \mathrm{kg}^{-1}\right)$ in cut clematis flowers

\begin{tabular}{|c|c|c|c|c|}
\hline \multirow{2}{*}{ Cultivar } & \multirow{2}{*}{ After harvest ${ }^{1}$} & \multicolumn{3}{|c|}{ Postharvest treatment $^{2}$} \\
\hline & & Water & 8-HQC & $8-\mathrm{HQC}+2 \% \mathrm{~S}$ \\
\hline 'Comtesse de Bouchand' & $\mathrm{BC} 65.46 \mathrm{c}^{3}$ & $83.93 \mathrm{~d}$ & $41.31 \mathrm{~b}$ & $23.74 \mathrm{a}$ \\
\hline 'General Sikorski' & B $53.12 \mathrm{~b}$ & $61.32 \mathrm{c}$ & $76.13 \mathrm{~d}$ & $42.81 \mathrm{a}$ \\
\hline 'Julka' & D $112.68 d$ & $86.44 \mathrm{c}$ & $75.01 \mathrm{~b}$ & $51.83 \mathrm{a}$ \\
\hline 'Kiri Te Kanawa' & C $72.35 \mathrm{~d}$ & $65.90 \mathrm{c}$ & $17.33 \mathrm{a}$ & $41.95 \mathrm{~b}$ \\
\hline 'Maria Skłodowska-Curie' & A 20.97 c & $24.60 \mathrm{~d}$ & $17.77 \mathrm{~b}$ & $13.75 \mathrm{a}$ \\
\hline 'Westerplatte' & $\mathrm{BC} 63.70 \mathrm{~b}$ & $125.63 \mathrm{c}$ & $68.98 \mathrm{~b}$ & $7.58 \mathrm{a}$ \\
\hline
\end{tabular}

${ }^{\mathrm{T}}$ The ammonium content immediately after cutting flowers

${ }^{2}$ The ammonium content on a day when control flowers (of a given cultivar) kept in water lost their decorative value - see Material and Methods

${ }^{3}$ Means in the first column followed by the same capital letter do not differ significantly at probability level $\mathrm{P}=95 \%$. Means in each verse followed by the same small letter do not differ significantly at probability level $\mathrm{P}=95 \%$. Analyses were done separately for each cultivar.

\section{Discussion}

Flower longevity is related to its sugar content. In typical cases, the vase life of flowers with higher sugar content is longer, that of flowers with lower sugar content it is shorter (Pun and Ichimura, 2003). In cut clematis flowers, a high initial carbohydrate pool did not guarantee long postharvest longevity. The highest reducing sugar level was observed in cv. 'Rhapsody' with the average vase life of 6 days, while the lowest sugar level was in the longer lasting 'Solidarność' (9 days) and the short living 'Lech Wałęsa' (4 days) (Table 2). This is in line with the opinion of Eason et al. (1997) that the petal sugar content does not always correlate with flower longevity.

Petals commonly serve as nutrient sinks during development and typically exhibit energy exhaustion during late stages of senescence (Rogers, 2013). In wilting clematis flowers held in water the reducing sugar level was considerably lower than at harvest (Table 2). On the contrary, in flowers held in the standard preservative (SP), an accumulation of carbohydrates was observed in all 13 cultivars studied, reaching level approximately twice as high as in flowers held in water or in the biocide solution. However, these high sugar levels were not always associated with longer vase lives. An increase in the vase life due to the use of the preservative was observed only in four out of 13 cultivars ('Generał Sikorski', 'Lech Wałęsa', 'Mazury' and 'Ville de Lyon') (Rabiza-Świder et al., 2017b). In 9 cultivars, the vase life of flowers held in SP and showing more reducing sugars in their petals was comparable to the vase life of flowers held in water. However, this is not entirely surprising; petals showing the first visible senescence symptoms may still have high sugar concentrations (van Doorn, 2004). The first visible signs of senescence in
Sandersonia flowers treated with sucrose occurred prior to any net loss of soluble carbohydrate (Eason et al., 1997).

No association between the duration of the vase life and the initial levels of soluble proteins was evident. There was a two-fold difference in the initial levels of soluble proteins in two long living cultivars - 'Arabella' and 'Blue Light' (Rabiza-Swider et al., 2017b) an even greater difference separated the two short living cultivars: flowers of cv. 'Lech Wałęsa' had 14 times more soluble proteins than the flowers of cv. 'Doctor Ruppel', both with the vase life of only four days (Table 3). The longevity of cv. 'Rhapsody' is only half of that of cv. 'Mazury' even though its initial protein level was twice as high. Published data generally show a drop in the protein contents in wilting flowers, but in some species this drop can be smaller than in others. For example, in Sandersonia petals, Eason et al. (2002) noticed only a small reduction. In clematis, the soluble protein levels declined in senescing cut flowers of all cultivars (Table 3 ). The range of this decrease was very variable, from two fold in the short living 'Andromeda', in medium longevity 'General Sikorski' and long living 'Solidarność', to 22-fold in 'Blue Light' with the vase life of 11 days. In another cultivar with a similar vase life span, cv. 'Arabella', the soluble protein level dropped 7-fold. Therefore, the longevity of cut clematis flowers does not appear to be associated with the initial levels of soluble proteins nor with the rate of their degradation.

In senescing flower petals the level of water-soluble and water-insoluble proteins may be affected by increased peptidase activity (Lerslerwong et al., 2009). In this study, the proteolytic activity at harvest differed considerably in different cultivars and increased during vase life (Table 4). The highest initial activity was in cv. 'Lech Wałęsa' with the shortest vase life of 4 days. The lowest (close to zero) initial 
438

activity was in cultivars 'Arabella', 'Blue Light' and 'Rhapsody'. However, there was no relationship between the initial proteolytic activity and flower longevity as cultivars 'Arabella' and 'Blue Light' have the vase life of 11 days while cv. 'Rhapsody' is 5-6 days. In all cultivars, the proteolytic activity increased during vase life, usually 2-3 times relative to the initial value (Table 4). Enormous increase (30-fold) was noted in cv. 'Blue Light', the cultivar with a very low initial proteolytic activity. Similarly, in Iris (van Doorn et al., 2003) and Sandersonia (Eason et al., 2002) flowers showed large increases in peptidase activity. In contrast, in Ipomoea petals, the soluble protein levels declined drastically, although no increase in peptidase activity was observed (Matile and Winkenbach, 1971). In senescing Dendrobium petals, an increase in peptidase activity did not affect the level of soluble proteins but affected the level of water-insoluble proteins (Lerslerwong $e t$ al., 2009).

Proteolysis in plants is a complex process involving many enzymes, with cysteine proteases playing an essential role. Their share in the total activity of proteases can be different in different plants and different organs. Wiśniewski and Zagdańska (2001) reported that cysteine protease activity in mature non-senescing organs amounts up to $30 \%$ of the total proteolytic activity. However, cysteine proteinases are responsive to a range of factors and in some cases they constitute up to $90 \%$ of the total proteolytic activity (Wiśniewski and Zagdańska, 2001). In clematis flowers immediately after harvest, that cysteine protease activity amounted up to $95 \%$ of the total proteolytic activity. In wilting flowers, this activity was similar. It needs to be pointed out that clematis flowers are cut when fully open and this means that degradative changes might have begun before harvest. In most species studied so far an increase in the peptidase activity occurred just before the first senescence symptoms became visible (Lerslerwong et al., 2009).

Holding solutions composed of 8-HQC or 8-HQC + sucrose limited the increase in proteolytic activity (Table 4), including that of cysteine protease (Table 5), as well as protein degradation (Table 3), and in all cases the standard preservative was more effective than the biocide solution. However, this positive SP effect on proteolysis was not always reflected in a longer vase life. Only in four cultivars ('General Sikorski', 'Lech Wałęsa', 'Mazury', 'Ville de Lyon') with higher soluble protein contents and lower proteolytic activity, the postharvest longevity was improved by the $\mathrm{SP}$ as compared to flowers held in water (Rabiza-Świder et al., 2017b). A similar situation was observed in Sandersonia flowers treated with sucrose which contained larger quantities of soluble protein than control flowers, and the first visible signs of senescence occurred prior to any loss of soluble carbohydrate or protein (Eason et al., 1997).

In cut clematis flowers the ammonium content increased during vase life and both holding solutions with 8HQC limited this increase (Table 7). Lauriere and Daussant (1983) suggested that ammonium accumulation might be a factor contributing to senescence. Yang and Kao (2000) showed that ammonium accumulation in leaves of water-stressed rice is associated with proline accumulation. Here we show that proline accumulation is related to senescence in clematis, similarly to other species (Zhang and Becker 2015). However, the final proline levels depended on a cultivar and the treatment (Table 6). The proline increase in clematis was not as dramatic as that in petals of senescing cut roses where a 14-fold increase in free proline content was observed (Kumar et al., 2009). In clematis, this increase was not more than 1.5 -fold relative to the initial value (Table 6). It has not yet been fully explored whether increased proline content contributes to flower senescence or it is only a consequence of senescence. Interestingly, Kumar et al. (2009) showed that at the final phase of rose senescence proline levels decreased by $50 \%$. They claimed that loss of endogenous proline correlates with the end of senescence and termination of vase life (Kumar et al., 2009). On the other hand, proline can be unleashed as a fuel source for the ATP production during flower senescence (Zhang and Becker, 2015). In cut tulips, sucrose supplementation helps maintain the ATP levels and increases the vase life (Azad et al., 2008). Zhang and Becker (2015) suggest that proline catabolism may delay petal senescence by preventing depletion of ATP. Evidence supporting utilization of proline during senescence was shown by treating flowers with substances which prolong their vase life (Zhang and Becker, 2015). In flowers of most clematis cultivars kept in the preservative solution free proline contents were lower than in flowers held in water (Table 6). However, this did not correlate with a prolonged vase life as only in 3 out of 6 cultivars the SP positively affected longevity ('Generał Sikorski', 'Kiri Te Kanawa', 'Maria Skłodowska-Curie') (Rabiza-Świder et al., 2017b), the proline content was lower by 32,44 and $79 \%$, respectively, than in flowers held in water and having shorter vase life (Table 6). Also, treatment of lisianthus flowers with salicylic acid which prolonged their vase life, correlated with a $75 \%$ reduction in proline level (Kazemi et al., 2011). Similarly, an extension of carnation vase life by aminooxyacetic acid correlated with the $40 \%$ decline in free proline content in senescing petals (Yakimova et al., 1997).

\section{Conclusions}

During senescence of cut clematis flowers degradative changes typical for senescence such as decline in reducing sugar content, degradation of soluble proteins due to an elevated proteolytic activity, increase in free proline and ammonium do take place. However, the longevity of cut clematis flowers among the cultivars tested was not associated with the initial contents of reducing sugars, soluble proteins or free proline. Holding solutions with 8HQC significantly affected the levels of the above compounds, with the biocide + sucrose (SP) being more effective. In wilting flowers placed into the standard preservative the sugar and protein contents were often higher while those of free proline and ammonium lower than in flowers held in water. These points to a significant role of the exogenous sucrose in controlling the senescence of cut clematis flowers. However, as a delay in the senescence-related changes by the preservative is not always associated with longer vase life additional tests are needed to control senescence in clematis, and to elucidate the role of exogenous sugar. 


\section{Acknowledgements}

This work was supported by the Ministry of Science and Higher Education under Grant N N310 089336.

\section{References}

Azad AK, Ishikawa T, Ishikawa T, Sawa Y, Shibata H (2008). Intracellular energy depletion triggers programmed cell death during petal senescence in tulip.Journal of Experimental Botany 59:2085-2095.

Azeez A, Sane AP, Bhatnagar D, Nath P (2007). Enhanced expression of serine proteases during floral senescence in Gladiolus. Phytochemistry 68:1352-1357.

Bates LS, Waldren RP, Teare ID (1973). Rapid determination of free proline for water-stress studies. Plant and Soil 39:205-207.

Bradford MM (1976). A rapid and sensitive method for the quantification of microgram quantities of protein utilizing the principle of protein dyebinding. Analytical Biochemistry 72:248-254.

Britto DT, Kronzucker HJ (2002). $\mathrm{NH}_{4}^{+}$toxicity in higher plants: a critical review. Journal of Plant Physiology 159:567-584.

Brzin J, Kidrič M (1996). Proteinases and their inhibitors in plants: Role in normal growth and in response to various stress conditions. Biotechnology and Genetic Engineering Reviews 13:421-468.

Chen SJ, Hung KT, Kao CH (1997). Ammonium accumulation is associated with senescence of rice leaves. Plant Growth Regulation 21:195-201.

Courts GD, Gartner JB, McCollum JP (1965). Effect of senescence and preservative on respiration in cut flowers of Rosa bybrida 'Velvet Times'. Proceedings of American Society of Horticultural Science 86:779-780.

Eason JR, de Vré LA, Somerfield SD, Heyes JA (1997). Physiological changes associated with Sandersonia aurantiaca flower senescence in response to sugar. Postharvest Biology and Technology 12:43-50.

Eason JR, Ryan DJ, Pinckney TT, O’Donoghue EM (2002). Programmed cell death during flower senescence: isolation and characterization of cysteine proteinases from Sandersonia aurantiaca. Functional Plant Biology 29:1055-1064.

Feller U, Fischer A (1994). Nitrogen metabolism in senescingleaves. Critical Reviews in Plant Sciences 13:241-273.

Fichman Y, Gerdes SY, Kovacs H, Szabados L, Zilberstein A, Csonka LN (2015). Evolution of proline biosynthesis: enzymology, bioinformatics, genetics, and transcriptional regulation. Biological Reviews Cambridge Philosophical Society 90:1065-1099.

Granell A, Cercos M, Carbonell J (1998). Plant cysteine proteinases in germination and senescence. In: Barrett AJ, Rawlings ND, Woessner JF (Eds). The handbook of proteolytic enzymes. San Diego, London Academic Press pp 578-583.

Halevy AH, Mayak S (1979). Senescence and postharvest physiology of cut flowers, part 1.Horticultural Reviews 1:204-236.

HongZ, Lakkineni K, Zhang Z, Verma DPS (2000). Removal of feedback inhibition of 1-pyrrolline-5-carboxylate synthetase results in increased proline accumulation and protection of plants from osmotic stress. Plant Physiology 122:1129-1136.
Ichimura K, Kohata K, Goto R (2000). Soluble carbohydrates in Delphinium and their influence on sepal abscission in cut flowers. Physiologia Plantarum 108:307-313.

Jędrzejuk A, Rochala J, Zakrzewski J, Rabiza-Świder J (2012). Identification of xylem occlusions occurring in cut clematis (Clematis L, fam. Ranunculaceae Juss.) stems during their vase life. The Science World Journal Article ID 749281.

Jones ML, Chaffin GS, Eason JR, Clark DG (2005). Ethylene-sensitivity regulates proteolytic activity and cysteine protease gene expression in petunia corollas. Journal of Experimental Botany 56:2733-2744.

Kaltaler REL, Steponkus PL (1976). Factors affecting respiration in cut roses. Journal American Society for Horticultural Science 101:352-354.

Karolewski P (1996). Role of proline in higher plants under conditions of abiotic stress. Wiadomości Botaniczne 40:67-81.

Kazemi M, Aran M, Zamani S (2011). Extending the vase life of lisianthus (Eustoma grandiflorum Mariachi cv. Blue) with different preservative. American Journal of Plant Physiology 6:167-175.

Kumar N, Pal M, Srivastava GC (2009). Proline metabolism in senescing rose petals (Rosa hybrida L. 'First Red'). The Journal of Horticultural Science and Biotechnology 84:536-540.

Lauriere C, Daussant J (1983). Identification of ammonium dependent isoenzyme of glutamate dehydrogenase as the form induced by senescence or darkness stress in the first leaf of wheat. Physiologia Plantarum 58:89-92.

Lerslerwong L, Ketsa A, van Doorn WG (2009). Protein degradation and peptidase activity during petal senescence in Dendrobium cv. Khao Sanan. Postharvest Biology and Technology 52:84-90.

Lin CC, $\mathrm{Kao} \mathrm{CH}$ (1996). Distributed ammonium assimilation is associated with growth inhibition of roots in rice seedlings caused by $\mathrm{NaCl}$. Plant Growth Regulation 18:233-238.

Lin CC, Hsu YT, Kao CH (2002). Ammonium ion, ethylene, and NaClinduced senescence of detached rice leaves. Plant Growth Regulation 37:85-92.

Matile P, Winkenbach F (1971). Function of lysosomes and lysosomalenzymes in the senescing corolla of morning glory (Ipomoea purpurea). Journal of Experimental Botany 22:759-771.

Nelson N (1944). A photometric adaptation of the Samogyi method for the determination of glucose.Journal Biology Chemistry 153:357-380.

Pak C, van Doorn WG (2005). Delay of Iris flower senescence by protease inhibitors. New Phytologist 165:473-480.

Paulin A (1971). Influence de la composition de la solution nutritive sur la teneur en divers acidés amines libres et en ammoniac des pétales de roses coupées [The effect of the preservative composition on the contents of free amino acids and ammonium in cut rose petals]. Annual Technology Agriculture 20:283-303.

Pun UK, Ichimura K (2003). Role of sugars in senescence and biosynthesis of ethylene in cut flowers. Japan Agricultural Research Quarterly 37:219-224.

Rabiza-Swider J, Skutnik E, Jędrzejuk A (2017a). The effect of preservatives on water balance in cut clematis flowers. The Journal of Horticultural Science and Biotechnology 92:270-278. 
440

Rabiza-ŚwiderJ,SkutnikE,Jędrzejuk A, Łukaszewska A (2017b).Extending the vase life of cut clematis flowers. Acta Scientiarum Polonorum Hortorum Cultus 16:51-60.

Rogers HJ (2013). From models to ornamentals: how is flower senescence regulated? Plant Molecular Biology 82:563-574.

Rubinstein B (2000). Regulation of cell death in flower petals. Plant Molecular Biology 44:303-318.

Stephenson P, Rubinstein B (1998). Characterization of proteolytic activity during senescence in daylilies. Physiologia Plantarum 104:463-473.

Sugawara H, Shibuya K, Yoshioka T, Hashiba T, Satoh S (2002). Is a cysteine proteinase inhibitor involved in the regulation of petal wilting in senescing carnation (Dianthus caryophyllus L.) flowers? Journal of Experimental Botany 53:407-413.

Valpuesta V, Lange NE, Guerrero C, Reid MS (1995). Upregulation of cysteine protease accompanies the ethylene in sensitive senescence of daylily (Hemerocallis) flowers. Plant Molecular Biology 28:575-582.

van Doorn WG (2004). Is petal senescence due to sugar starvation? Plant Physiology 134:35-42.

van Doorn WG, Balk PA, van Houwelingen AM, Hoeberichts FA, Hall $\mathrm{RD}$, Vorst $\mathrm{O}, \ldots$ van Wordragen MF (2003). Gene expression during anthesis and senescence in Iris flowers. Plant Molecular Biology 53:845863.

Vierstra RD (1996). Proteolysis in plants: mechanism and functions. Plant Molecular Biology 32:275-302.
WagstaffC, Leverentz MK, Griffiths G, Thomas B, Chanasut U,Stead AD, Rogers HJ (2002). Cysteine protease gene expression and proteolytic activity during senescence of Alstroemeria petals. Journal of Experimental Botany 53:233-240.

Weatherburn MW (1967). Phenol-hypochloride reaction for determination of ammonia. Analytical Chemistry 39:971-974.

Weinstein LH (1957). Senescence of roses: I. Chemical changes associated with senescence of cut 'Better Times' roses. Contributions of the Boyce Thompson Institute 19:33-48.

Wiśniewski K, Zagdańska B (2001). Genotype-dependent proteolytic response of spring wheat to water deficiency. Journal of Experimental Botany 52:1455-63.

Yakimova E, Atanassova B, Kapchina-Toteva V (1997). Longevity and some metabolic events in postharvest spray-carnation (D. caryophyllus $\mathrm{f}$. spray, Hort) flowers. Bulgarian Journal Plant Physiology 23:57-65.

Yang CW, Kao CH (2000). Ammonium in relation to proline accumulation in detached rice leaves. Plant Growth Regulation 30:139144.

Zagdańska B, Wiśniewski K (1996). Endoproteinase activities in wheat leaves upon water deficit. Acta Biochimica Polonica 43:515-520.

Zhang L, Becker DF (2015). Connecting proline metabolism and signaling pathways in plant senescence. Frontiers in Plant Science 6:1-8. 